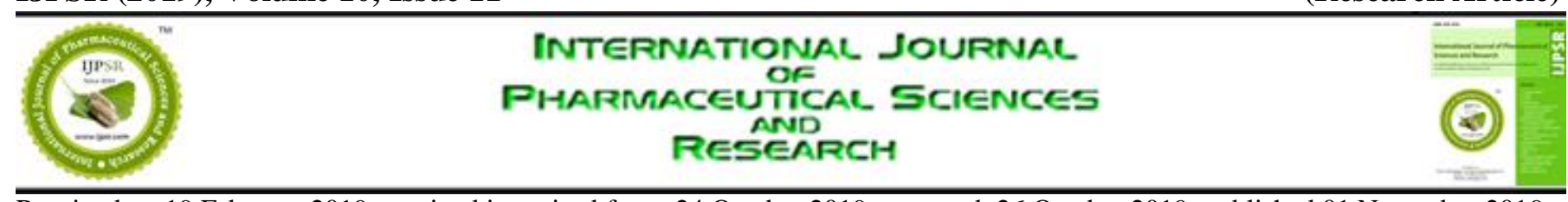

Received on 19 February 2019; received in revised form, 24 October 2019; accepted, 26 October 2019; published 01 November 2019

\title{
STABILITY INDICATING RP-HPLC METHOD FOR THE SIMULTANEOUS ESTIMATION OF PANTOPRAZOLE AND LEVOSULPIRIDE IN PHARMACEUTICAL DOSAGE FORM
}

\author{
Nivedeetha Halekote Shivaraju, Gullapalli Kowmudi, Karthika Anoop and Krishnaveni Nagappan
}

Department of Pharmaceutical Analysis, JSS College of Pharmacy, [A Constituent College - JSS Academy of Higher Education \& Research] Udhagamandalam - 643001, Tamil Nadu, India.

Keywords:

Stability indicating RP HPLC, Stress degradation, Levosulpiride, Pantoprazole

\section{Correspondence to Author: \\ Dr. Krishnaveni Nagappan}

Department of Pharmaceutical Analysis, JSS College of Pharmacy, [A Constituent College - JSS Academy of Higher Education \& Research] Udhagamandalam 643001, Tamil Nadu, India.

E-mail: krisath@gmail.com

\begin{abstract}
Simple, sensitive, and rapid stability indicating RP-HPLC method for simultaneous estimation of Pantoprazole and Levosulpiride in pharmaceutical dosage form was developed and validated. The analysis was carried out on Hibar $\mathrm{C}_{18}$ column $(250 \times 4.6 \mathrm{~mm}$, id, $5 \mu)$ and the mobile phase composition was $10 \mathrm{mM}$ ammonium acetate $(\mathrm{pH} 4.0$ adjusted using acetic acid): Acetonitrile in the ratio of $20: 80 \% \mathrm{v} / \mathrm{v}$ with a flow rate of $1.0 \mathrm{~mL} / \mathrm{min}$ at room temperature. The sample injection volume was $20 \mu \mathrm{L}$, and eluents of the isocratic elution mode were monitored at $241 \mathrm{~nm}$. The retention time was $3.1 \mathrm{~min}$ and $5.2 \mathrm{~min}$ for Pantoprazole and Levosulpiride, respectively. The method was linear in the concentration range of $1-7 \mu \mathrm{g} / \mathrm{ml}$ for Pantoprazole sodium with an $r^{2}$ of 0.9973 and $4-10 \mu \mathrm{g} / \mathrm{ml}$ of Levosulpiride with an $r^{2}$ of 0 . 9961. The LOD and LOQ were found to be 0.05 and $1.5 \mu \mathrm{g} / \mathrm{ml}$ for Pantoprazole and Levosulpiride. The drug stability was assessed under various stress degradation conditions at room temperature for $24 \mathrm{~h}$. In photodegradation, the percentage of degradation of Levosulpiride and Pantoprazole when exposed to sunlight for $8 \mathrm{~h}$ was found to be $42.7 \%$ and $2.75 \%$, respectively. Whereas under other stress conditions viz acidic, basic, and oxidative degradation studies carried out for $24 \mathrm{~h}$, the $\%$ degradation of the active constituent was found to be $23.21 \%, 21.98 \%$, and $22.98 \%$ for Levosulpiride \& $100 \%, 100 \%$ and $66.78 \%$ for Pantoprazole respectively. The proposed method was validated as per ICH guidelines Q2B.
\end{abstract}

INTRODUCTION: Pantoprazole (PT), a derivative of substituted benzimidazole is a proton pump inhibitor and used in the short-term treatment of Gastroesophageal reflux disease (GERD). It suppresses the final step involved in gastric acid production by covalently binding to the $\left(\mathrm{H}^{+}, \mathrm{K}^{+}\right)$ATPase enzyme system at the secretory surface of the gastric parietal cell.

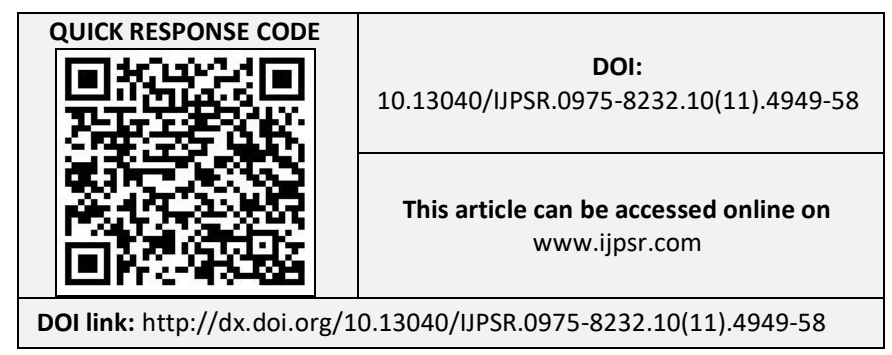

This effect leads to the inhibition of both basal and stimulated gastric acid secretion, irrespective of the stimulus. The binding to the $\left(\mathrm{H}^{+}, \mathrm{K}^{+}\right)$-ATPase results in the anti-secretory effect that persists longer than $24 \mathrm{~h}$ for all the doses tested ${ }^{1,2}$. Levosulpiride (LS) is the levorotatory enantiomer of the Sulpiride, a substantial benzamide derivative. It is a typical antipsychotic agent used in the treatment of anxiety disorders, depression, schizophrenia and peptic ulcers ${ }^{3,4}$. Levosulpiride selectively blocks Dopaminergic $\mathrm{D}_{2}$ receptors at the central level and at the submucosal and myenteric plexus peripheral level, which interact with the cholinergic, adrenergic, and peptidergic fibers to regulate the motility of the gastrointestinal tract $(\mathrm{GIT})^{5}$. 
Combined administration of both the drugs had shown proven activity against Gastro-Esophageal Reflux Disease (GERD). GERD results in regurgitation of the gastric contents into the lower esophagus with following symptoms like heartburn, retrosternal pain, dysphagia, and belching ${ }^{6}$.

A thorough review of the literature revealed a Spectrophotometric method for the quantification of Levosulpiride in bulk drug and formulation ${ }^{7}$. A UV method ${ }^{8}$ for quantification in dissolution samples, HPTLC, and validated HPLC methods were reported for the simultaneous quantification of Levosulpiride with rabeprazole sodium ${ }^{9-13}$. Validated HPTLC methods were reported for the simultaneous quantification of Levosulpiride and esomeprazole in capsule dosage forms ${ }^{14,15}$. A UPLC method with QbD approach for the simultaneous quantification of Levosulpiride and rabeprazole was also reported ${ }^{16}$.

Patel and coworkers reported a validated RP-HPLC method for the analysis of levosulpiride and pantoprazole sodium. The separation was carried out in an isocratic mode using a $\mathrm{C}_{18}$ column with water: Acetonitrile: trimethylamine (60:40:0.25 $\mathrm{v} / \mathrm{v} / \mathrm{v})$ as the mobile phase ${ }^{17}$. Kothapalli and coworkers reported stability indicating RP-HPLC method for the simultaneous quantification of pantoprazole and levosulpiride in combined dosage forms. The separation was carried out on a thermos BDS $\mathrm{C}_{18}$ column utilizing $0.02 \mathrm{M}$ potassium dihydrogen orthophosphate solution $(\mathrm{pH} 4)$ : Acetonitrile (60: $40 \mathrm{v} / \mathrm{v})$ at a flow rate of 1.0 $\mathrm{ml} / \mathrm{min}$. Forced degradation studies under various stress conditions were also carried out and reported 18

SG Khanage and coworkers had reported an RP HPLC method for the simultaneous estimation of levosulpiride and pantoprazole sodium in a capsule dosage form. The quantification was carried out on a $\mathrm{C}_{18}$ column with methanol: $5 \mathrm{mM}$ ammonium acetate buffer $(\mathrm{pH} 4)$ at the ratio of 70:30 v/v ${ }^{[19]}$. Kaliselvi and coworkers reported an RP HPLC method for the simultaneous quantification of levosulpiride and pantoprazole in tablets ${ }^{20}$.

From the literature survey it was evident that the methods reported for the simultaneous quantification of pantoprazole sodium and levosulpiride suffer from LC-MS incompatibility and longer retention times. Also, the analytical stability methods reported utilize phosphate buffers which are not LC-MS compatible and thus may not support method transfer during the characterization of the degradation products. Therefore, the objective of the present work is to develop and validate a stability-indicating RP HPLC method, which will be compatible with high-end analytical instruments for the simultaneous quantification of pantoprazole and levosulpiride. Stress degradation studies will also be carried out as per standard ICH guidelines $^{21,22}$.

\section{MATERIALS AND METHODS:}

Chemicals, Reagents, and Solutions: HPLC grade Methanol and Acetonitrile, AR grade Hydrochloric Acid, Sodium Hydroxide, and Hydrogen Peroxide were procured from SD Fine Chem. Ltd., (Mumbai, India). Ammonium acetate AR Grade was procured from Rankem Laboratories (India). Millipore water from milli-Q RO system was used. Borosilicate glassware (Class A) was used for the preparation of solutions. Working standards of pantoprazole sodium were procured from Ranbaxy Laboratories, New Delhi, and levosulpiride from INC Chem Laboratories, Hyderabad. Pantocid-L capsule formulation marketed by Sun pharma was procured from the local pharmacy, The Nilgiris, Tamil Nadu.

Chromatographic Conditions: Chromatographic separations were performed on a Shimadzu gradient HPLC system equipped with LC-10 ATVP solvent delivery system (pump), an Autosampling injector with $20 \mu 1$ loop volume and SPD M-10A VP UV detector. CLASS VP software was used for data acquisition and handling. The analysis was carried out on a Hibar $\mathrm{C}_{18}$ column $(250 \times 4.6$ $\mathrm{mm}$, id, $5 \mu \mathrm{m})$ in isocratic elution mode with the mobile phase composition of $10 \mathrm{mM}$ ammonium acetate $(\mathrm{pH} 4.0$ adjusted using acetic acid) and acetonitrile $(20: 80 \% \mathrm{v} / \mathrm{v})$ at a flow rate of 1.0 $\mathrm{ml} / \mathrm{min}$ at room temperature. The eluents were monitored at $241 \mathrm{~nm}$. The $\mathrm{pH}$ measurements were carried out using a precalibrated Systronics $\mathrm{pH}$ meter 335 equipped with a glass electrode.

Assay of Marketed Formulation: About 10 capsules of the marketed formulation Pantocid were taken and weighed. A quantity of powder equivalent to label claim of pantoprazole and levosulpiride $(40 \mathrm{mg}$ pantoprazole and $70 \mathrm{mg}$ 
levosulpiride) was accurately weighed and transferred into a $50 \mathrm{ml}$ volumetric flask, acetonitrile was added and sonicated for $15 \mathrm{~min}$ at room temperature, filtered and made up to the mark with acetonitrile. About $0.1 \mathrm{ml}$ of the above solution was pipetted out into a $10 \mathrm{ml}$ volumetric flask, diluted with mobile phase and was injected under the optimized chromatographic condition and the chromatogram was recorded. The percentage of purity was calculated based on the peak area and reported.

Stress Degradation Studies: The stress degradation studies were performed under different stress conditions specified as per ICH Q1 guidelines. The mixture of drug solutions was prepared at $1 \mathrm{mg} / \mathrm{ml}$ for all the stress studies. After the studies, the aliquots of the samples were neutralized and suitably diluted with mobile phase to obtain $10 \mu \mathrm{g} / \mathrm{ml}$, and the samples were stored at $8^{\circ} \mathrm{C}$ until further analysis by the optimized chromatographic conditions. Blank solutions were also prepared at the same time as that of the stock solutions.

Preparation of Standard Stock Solutions: About $10 \mathrm{mg}$ of working standards PT and LS were accurately weighed and transferred into a $10 \mathrm{ml}$ volumetric flask and dissolved in HPLC grade Acetonitrile to obtain $1 \mathrm{mg} / \mathrm{ml}$ solution. The above stock solution was further diluted 10 times with $\mathrm{HCl}(0.1 \mathrm{M}), \mathrm{NaOH}(0.1 \mathrm{M})$, and Hydrogen Peroxide $(6 \%)$ for acid hydrolysis, base hydrolysis, and oxidative degradation studies. For photolytic degradation studies, the solid drug sample was taken in a petri dish and exposed to sunlight for 3 days.

\section{Acid Degradation:}

\section{Degradation Medium:}

Hydrochloric Acid (0.1 M): $1 \mathrm{ml}$ of the stock solutions (Pantoprazole sodium \& Levosulpiride) was taken in a $10 \mathrm{ml}$ volumetric flask, and the solution was made up to the mark with $0.1 \mathrm{M}$ Hydrochloric acid. The solution was kept at room temperature for $24 \mathrm{~h}$. The samples were withdrawn at $0,2,4,6,8,12$, and $24 \mathrm{~h}$ and stored in a refrigerator. $1.0 \mathrm{ml}$ of the solutions withdrawn was further neutralized with $1 \mathrm{ml}$ of $0.1 \mathrm{M}$ Sodium hydroxide and made up to the mark with diluent (80:20 acetonitrile: $10 \mathrm{mM}$ ammonium acetate $\mathrm{pH}-$
4.0) in a $10 \mathrm{ml}$ volumetric flask. They were analyzed under optimized chromatographic conditions, and the chromatograms were recorded.

\section{Base Degradation: \\ Degradation Medium:}

Sodium Hydroxide (0.1 M): $1 \mathrm{ml}$ of the stock solutions (Pantoprazole sodium \& Levosulpiride) was taken in a $10 \mathrm{ml}$ volumetric flask, and the solution was made up to the mark with $0.1 \mathrm{M}$ sodium hydroxide. The solution was kept at room temperature for $24 \mathrm{~h}$. The samples were withdrawn at $0,2,4,6,8,12$, and $24 \mathrm{~h}$ and stored in a refrigerator.

$1.0 \mathrm{ml}$ of the solutions withdrawn was further neutralized with $1 \mathrm{ml}$ of $0.1 \mathrm{M}$ Hydrochloric acid and made up to the mark with diluents (80:20 acetonitrile: $10 \mathrm{mM}$ ammonium acetate $\mathrm{pH}-4.0$ ) in a $10 \mathrm{ml}$ volumetric flask. They were analyzed under optimized chromatographic conditions, and the chromatograms were recorded.

\section{Oxidative Degradation:}

Degradation Medium:

Hydrogen Peroxide (6\%): $1.0 \mathrm{ml}$ of the stock solutions (Pantoprazole sodium \& Levosulpiride) was taken in a $10 \mathrm{ml}$ volumetric flask and the solution was made up to the mark with $6 \%$ Hydrogen Peroxide. The solution was kept at room temperature for $24 \mathrm{~h}$. The samples were withdrawn at $0,2,4,6,8,12$, and $24 \mathrm{~h}$. $1.0 \mathrm{ml}$ of the solution withdrawn was further diluted with diluents $(80: 20$, acetonitrile: $10 \mathrm{mM}$ ammonium acetate $\mathrm{pH}-4.0$ ) in a $10 \mathrm{ml}$ volumetric flask. They were analyzed under optimized chromatographic conditions, and the chromatograms were recorded.

\section{Photolytic Degradation: Degradation Medium:}

Sunlight: $25 \mathrm{mg}$ of pantoprazole sodium \& levosulpiride were taken individually on a watch glass and exposed to sunlight for $8 \mathrm{~h} /$ day for 3 days. $1 \mathrm{mg} / \mathrm{ml}$ solutions were prepared from the above-exposed samples. The solutions were further diluted to obtain a final concentration of $10 \mu \mathrm{g} / \mathrm{ml}$ with diluent $(80: 20 \% \mathrm{v} / \mathrm{v}$ acetonitrile: $10 \mathrm{mM}$ ammonium acetate $\mathrm{pH}-4.0)$. The samples of photolytic degradation were analyzed under optimized chromatographic conditions, and the chromatograms were recorded. 


\section{Thermal Degradation:}

Degradation Medium:

Temperature $80^{\circ} \mathrm{C}$ : $25 \mathrm{mg}$ of pantoprazole sodium $\&$ levosulpiride were taken individually on a watch glass and kept in an oven at $80^{\circ} \mathrm{C}$ for $8 \mathrm{~h} .1 \mathrm{mg} / \mathrm{ml}$ solutions were prepared from the above solution with the diluent. The solutions were further diluted to obtain a final concentration of $10 \mu \mathrm{g} / \mathrm{ml}$ with diluent (80:20 acetonitrile: $10 \mathrm{mM}$ ammonium acetate $\mathrm{pH}-4.0)$. The samples of thermal degradation were analyzed under optimized chromatographic conditions, and the chromatograms were recorded.

\section{RESULTS AND DISCUSSION:}

Optimization of Chromatographic Conditions: Optimization of the chromatographic conditions is intended to reach out various goals of the method development to weigh each goal (resolution, runtime, sensitivity, peak symmetry, etc.,) accurately according to the requirements of HPLC that can be used for the estimation of pantoprazole and levosulpiride in their degradation samples. A mobile phase composition of acetonitrile: $10 \mathrm{mM}$ ammonium acetate $(\mathrm{pH} 4.0$ adjusted using acetic acid) as mobile phase in the ratio of $80: 20 \% \mathrm{v} / \mathrm{v}$ at a flow rate of $1.0 \mathrm{ml} / \mathrm{min}$ was used for optimized separation of pantoprazole and levosulpiride on a $\mathrm{C}_{18}$ column $(250 \times 4.6 \mathrm{~mm}$. id, $5 \mu \mathrm{m})$ as stationary phase. The separation was carried out at room temperature, and the eluents were monitored using a UV detector at $241 \mathrm{~nm}$. The contents of the mobile phase and all the samples were filtered through a $0.45 \mu$ membrane filter and degassed before analysis. The chromatographic separation was carried out on a Shimadzu gradient HPLC system. The typical retention times of pantoprazole and levosulpiride were about $3.1 \pm 0.2 \mathrm{~min}$ and 5.2 \pm 0.2 min, respectively.

Validation of the Stability Indicating Analytical Method: The developed RP-HPLC method was validated according to ICH Q2 R1 guidelines concerning linearity, accuracy, precision, specificity, selectivity, the limit of quantification and limit of detection.

Accuracy: The accuracy of the method was demonstrated by performing recovery studies at 3 levels. The results in Table 1 were found to be significant within the specification limits for pantoprazole and levosulpiride with percentage recovery of $98.38-99.7 \%$ and $98.7-100.16 \%$, respectively (within the limits of $98-102 \%$ ).

TABLE 1: EVALUATION OF THE ACCURACY OF PANTOPRAZOLE AND LEVOSULPIRIDE

\begin{tabular}{|c|c|c|c|c|c|c|}
\hline & & Pantoprazol & & & Levosulpiride & \\
\hline Amount spiked $(\mu \mathrm{g} / \mathrm{ml})$ & 2 & 4 & 6 & 5 & 7 & 9 \\
\hline$\%$ Recovery $\pm \%$ RSD & $98.5 \pm 0.02$ & $98.38 \pm 0.04$ & $99.07 \pm 0.02$ & $98.7 \pm 0.03$ & $100.16 \pm 0.02$ & $98.87 \pm 0.02$ \\
\hline
\end{tabular}

Precision: The precision studies were carried out at 3 different concentration level for pantoprazole (2, $4 \& 6 \mu \mathrm{g} / \mathrm{ml})$ and levosulpiride $(5,7 \& 9 \mu \mathrm{g} / \mathrm{ml})$. The $\%$ RSD values for inter-day and intra-day precision studies were less than $2 \%$ indicating that the method developed was highly precise. The intraday and inter-day precision were evaluated and reported in Table 2.

TABLE 2: PRECISION STUDIES OF PANTOPRAZOLE AND LEVOSULPIRIDE

\begin{tabular}{|c|c|c|c|c|c|c|}
\hline \multicolumn{7}{|c|}{ Intraday precision studies } \\
\hline \multirow[t]{2}{*}{ Peak area } & 82309 & 149943 & 210933 & 262724 & 363979 & 472376 \\
\hline & 82890 & 149949 & 219567 & 262162 & 365481 & 467291 \\
\hline$\%$ RSD & 0.46 & 0.06 & 2.67 & 0.49 & 0.30 & 0.705 \\
\hline \multicolumn{7}{|c|}{ Inter-day precision studies } \\
\hline \multicolumn{7}{|c|}{ Inter-day precision studies Day 1} \\
\hline Peak area & 78890 & 156789 & 220352 & 264767 & 369975 & 453897 \\
\hline Mean & $78393 \pm 664.87$ & $156705 \pm 1194.69$ & $218667 \pm 1858.24$ & $262895 \pm 3291.31$ & $370928 \pm 6822.07$ & $451795 \pm 5656.73$ \\
\hline$\%$ RSD & 0.848 & 0.762 & 0.849 & 1.252 & 1.839 & 1.25 \\
\hline \multicolumn{7}{|c|}{ Inter-day precision studies Day 2} \\
\hline Peak area & 82309 & 149942 & 210933 & 262724 & 363979 & 472376 \\
\hline
\end{tabular}




\begin{tabular}{ccccccc}
\hline & 82890 & 149949 & 219567 & 262162 & 365481 & 467291 \\
Mean & $82749 \pm 388.77$ & $150006 \pm 382.35$ & $217494 \pm 5810.87$ & $262162 \pm 1281.98$ & $365212 \pm 1123.36$ & $468615 \pm 388.77$ \\
\% RSD & 0.46 & 0.06 & 2.67 & 0.49 & 0.30 & 0.705 \\
\hline \multicolumn{7}{c}{ Inter-day precision studies Day 3 } \\
\hline Peak area & 79568 & 165471 & 227864 & 263884 & 387176 & 446438 \\
& 78638 & 165856 & 228753 & 262118 & 384632 & 454795 \\
& 79880 & 169877 & 225352 & 264787 & 380975 & 452869 \\
Mean & $79362 \pm 646.11$ & $167068 \pm 2440.27$ & $227323 \pm 1763.86$ & $263597 \pm 1357.55$ & $384261 \pm 3117.10$ & $451367 \pm 4376.19$ \\
\% RSD & 0.814 & 1.406 & 0.776 & 0.515 & 0.811 & 0.969 \\
\hline
\end{tabular}

Linearity: The linearity range for pantoprazole and levosulpiride was established from 1-7 $\mu \mathrm{g} / \mathrm{ml}$ and $4-10 \mu \mathrm{g} / \mathrm{ml}$ respectively Table 3 . The correlation coefficient $\left(\mathrm{r}^{2}\right)$ was found to be 0.9973 and 0.9961 for pantoprazole and levosulpiride, indicating that the method was linear. The linearity plot of pantoprazole and levosulpiride are given in Fig. 1 and 2.

TABLE 3: LINEARITY STUDIES

\begin{tabular}{cccc}
\hline \multicolumn{2}{c}{ Pantoprazole } & \multicolumn{2}{c}{ Levosulpiride } \\
\hline Concentration $(\boldsymbol{\mu g} / \mathbf{m l})$ & Peak area* $(* \mathbf{n}=\mathbf{3})$ & Concentration $(\boldsymbol{\mu g} / \mathbf{m l})$ & Peak area* $(* \mathbf{n}=\mathbf{3})$ \\
\hline 1 & 46729 & 4 & 207102 \\
2 & 78652 & 5 & 264811 \\
3 & 118214 & 6 & 305908 \\
4 & 155471 & 7 & 378176 \\
5 & 185902 & 8 & 409925 \\
6 & 216674 & 9 & 445392 \\
7 & 253748 & 10 & 520217 \\
\hline
\end{tabular}

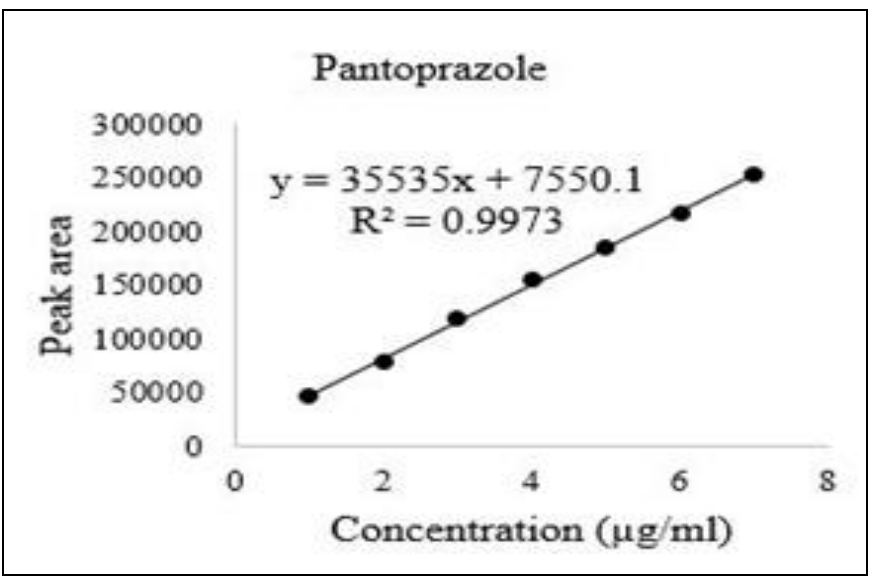

FIG. 1: LINEARITY OF PANTOPRAZOLE

Limit of Detection \& Limit of Quantification: The limit of detection (LOD) and limit of quantification (LOQ) for pantoprazole and levosulpiride was $0.05 \mu \mathrm{g} / \mathrm{ml}$ and $1.5 \mu \mathrm{g} / \mathrm{ml}$ Table 4 .

\section{TABLE 4: SYSTEM SUITABILITY}

\begin{tabular}{ccc}
\hline Parameters & Pantoprazole & Levosulpiride \\
\hline Linearity and Range & $1-7 \mu \mathrm{g} / \mathrm{ml}$ & $4-10 \mu \mathrm{g} / \mathrm{ml}$ \\
Regression equation & $\mathrm{y}=35535 \mathrm{x}+7550.1$ & $\mathrm{y}=51070 \mathrm{x}+3635.3$ \\
Correlation & 0.9973 & 0.9961 \\
coefficient $\left(\mathrm{r}^{2}\right)$ & & \\
Theoretical plates & 42711 & 24144 \\
Asymmetric factor & 1.0 & 1.0 \\
Tailing factor & 1.16 & 1.0 \\
Limit of Detection & $0.05 \mu \mathrm{g} / \mathrm{ml}$ & $0.05 \mu \mathrm{g} / \mathrm{ml}$ \\
(LOD) & & $0.15 \mu \mathrm{g} / \mathrm{ml}$ \\
Limit of & $0.15 \mu \mathrm{g} / \mathrm{ml}$ & \\
Quantification (LOQ) & & \\
\hline
\end{tabular}

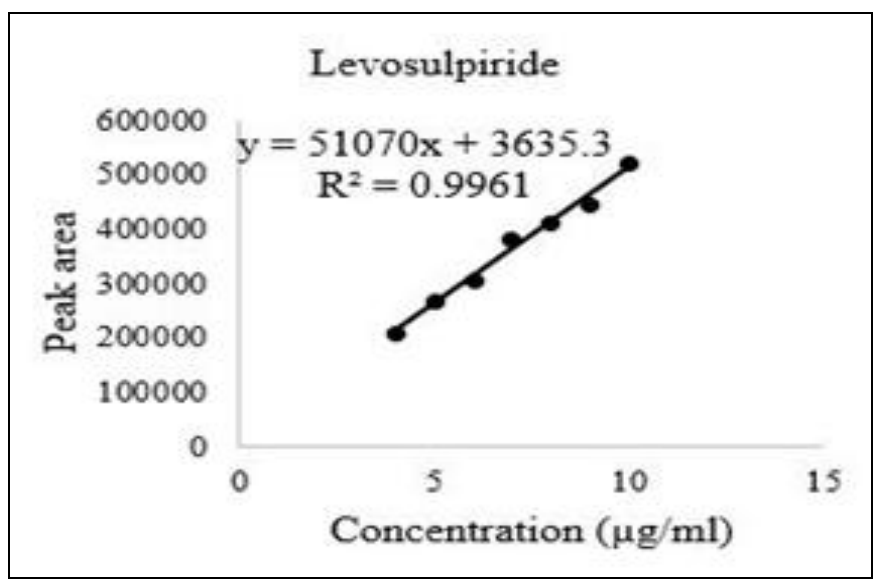

FIG. 2: LINEARITY OF LEVOSULPIRIDE

Robustness: The robustness of the method was determined by analyzing the samples under a variety of conditions with slight changes in flow rate $( \pm 0.1 \mathrm{ml} / \mathrm{min}), \mathrm{pH}( \pm 0.2$ units $)$, mobile phase ratio $( \pm 2 \%)$ and wavelength $( \pm 2 \mathrm{~nm})$. The $\%$ RSD for the robustness studies was less than $2 \%$ indicating that the method is robust.

Specificity: The specificity of the method was reasonable, and it was proven by analyzing the degraded samples. The resolution between the pantoprazole and levosulpiride and their degradation products were more than two indicating the specificity of the methods. 
DISCUSSION: In the preliminary expected run for the separation of pantoprazole and levosulpiride, a $\mathrm{C}_{18}$ column was used, and the trials were carried out using a mobile phase consisting of water and methanol at different ratios. Pantoprazole was not retained. Methanol was replaced by acetonitrile to modify the peak shape, but there was no improvement in the retention time of pantoprazole.

Thus, the aqueous phase was replaced with a buffer solution. The optimized conditions used for the estimation provided a distinct separation between degradation products produced during stress degradation studies. Validation for the method has been performed as per ICH guidelines, and results were documented.

Acidic Degradation: In acidic degradation studies, it was observed that the percentage degradation of pantoprazole sodium and levosulpiride at the end of $24 \mathrm{~h}$ at room temperature with $0.1 \mathrm{M}$ Hydrochloric acid was found to be 100 and $23.21 \%$ respectively. The percentage of degradation of drugs at various time intervals was recorded and represented in Table 5. The degradation products were observed in the following retention time 1.3, 2.60, 2.90, 3.73 and $4.38 \mathrm{~min}$, respectively and are depicted in Fig. 3 and 4.

\section{TABLE 5: DEGRADATION STUDIES}

\begin{tabular}{|c|c|c|c|c|c|c|}
\hline \multirow{2}{*}{$\begin{array}{l}\text { Degradation } \\
\text { medium }\end{array}$} & \multirow{2}{*}{$\begin{array}{c}\text { Sample } \\
\text { withdrawal } \\
\text { interval (hour) }\end{array}$} & \multirow{2}{*}{$\begin{array}{c}\text { Conc. of } \\
\text { drugs taken } \\
(\mu \mathrm{g} / \mathrm{ml})\end{array}$} & \multicolumn{2}{|c|}{ Degradants } & \multicolumn{2}{|c|}{ \% of degradation } \\
\hline & & & $\begin{array}{c}\text { No. of } \\
\text { degradants }\end{array}$ & $\begin{array}{c}\text { Rt of degradants } \\
\text { (min) }\end{array}$ & Pantoprazole & Levosulpiride \\
\hline $\begin{array}{c}0.1 \mathrm{M} \text { Hydrochloric } \\
\text { Acid (Room } \\
\text { temperature) }\end{array}$ & 24 & 10 & 5 & $\begin{array}{c}1.3,2.60,2.90 \\
3.73,4.38\end{array}$ & 100 & 23.21 \\
\hline $\begin{array}{l}0.1 \mathrm{M} \text { Sodium } \\
\text { hydroxide (Room } \\
\text { temperature) }\end{array}$ & 24 & 10 & 5 & $\begin{array}{c}2.49,2.77,3.62 \\
\quad 4.05,18.19\end{array}$ & 100 & 21.975 \\
\hline $\begin{array}{c}30 \% \text { Hydrogen } \\
\text { peroxide (Room } \\
\text { temperature) }\end{array}$ & 24 & 10 & 3.322 & 7.702 & 66.78 & 22.98 \\
\hline Sunlight & 8 & 10 & 2 & $1.82,2.45$ & 2.756 & 42.7 \\
\hline Heat $80^{\circ} \mathrm{C}$ & 8 & 10 & 1 & 8.52 & 8.52 & 0 \\
\hline
\end{tabular}

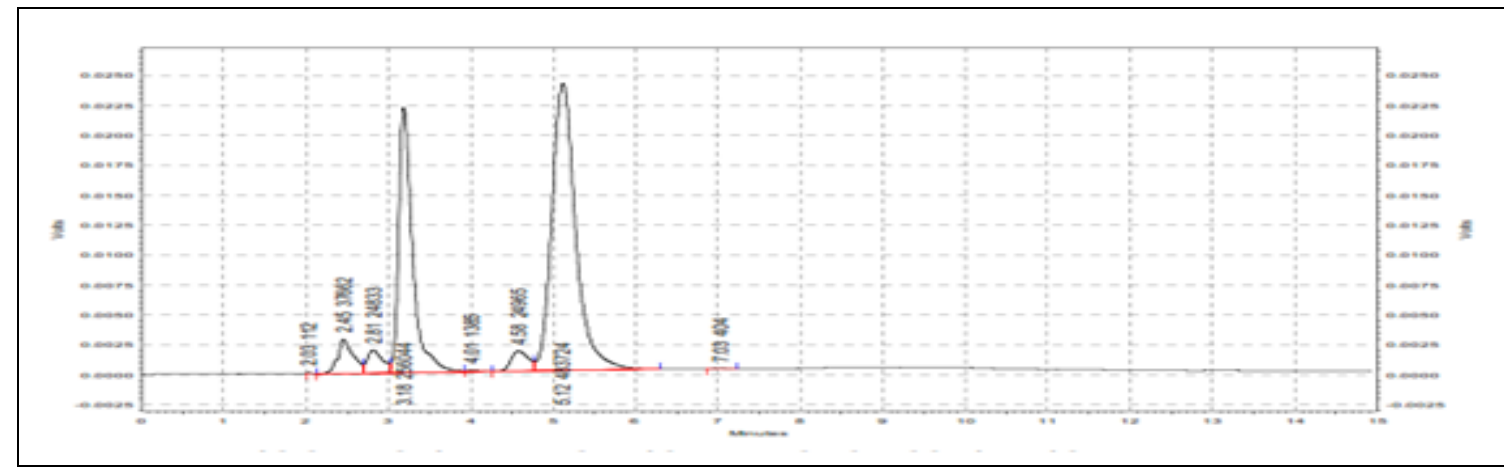

FIG. 3: ACID DEGRADATION SAMPLE WITH O.1M HYDROCHLORIC ACID AT ROOM TEMPERATURE WITHDRAWN AT $0 \mathrm{~h}$

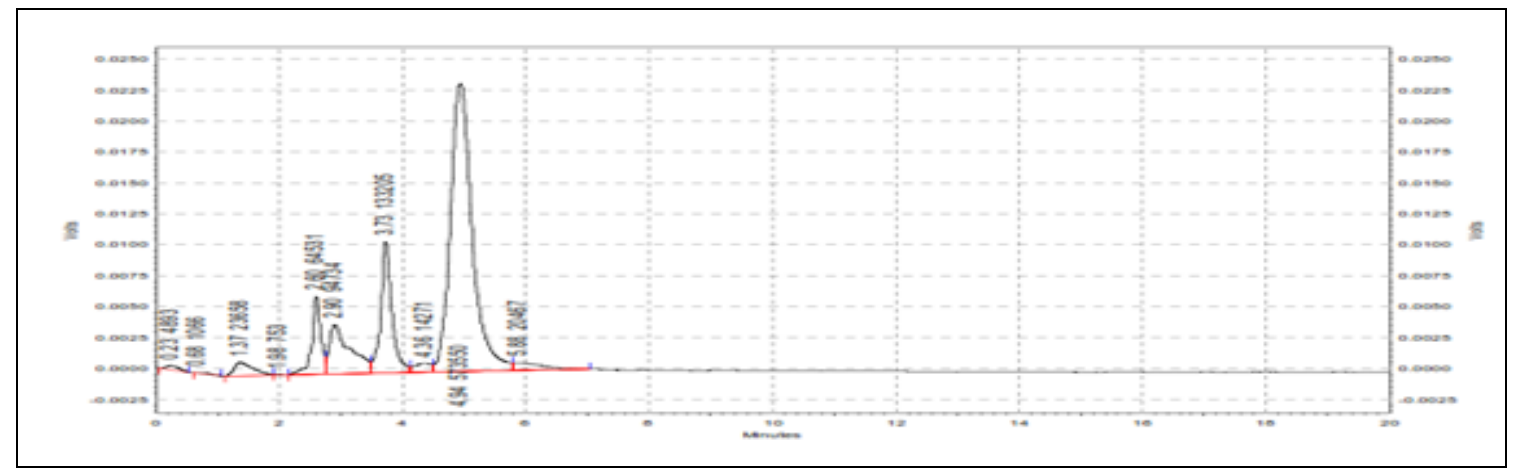

FIG. 4: ACID DEGRADATION SAMPLE WITH O.1M HYDROCHLORIC ACID AT ROOM TEMPERATURE WITHDRAWN AT 24 h 
Basic Degradation: In basic degradation studies, it was observed that the percentage degradation of pantoprazole sodium and levosulpiride at the end of $24 \mathrm{~h}$ at room temperature with $0.1 \mathrm{M}$ sodium hydroxide was found to be 100 and $21.975 \%$ respectively. The percentage of degradation of drugs at various time intervals was recorded and represented in Table 5. The degradation products were observed in the following retention time 2.49, $2.77,3.62,4.05$ and $18.19 \mathrm{~min}$. respectively and depicted in Fig. 5 and 6.

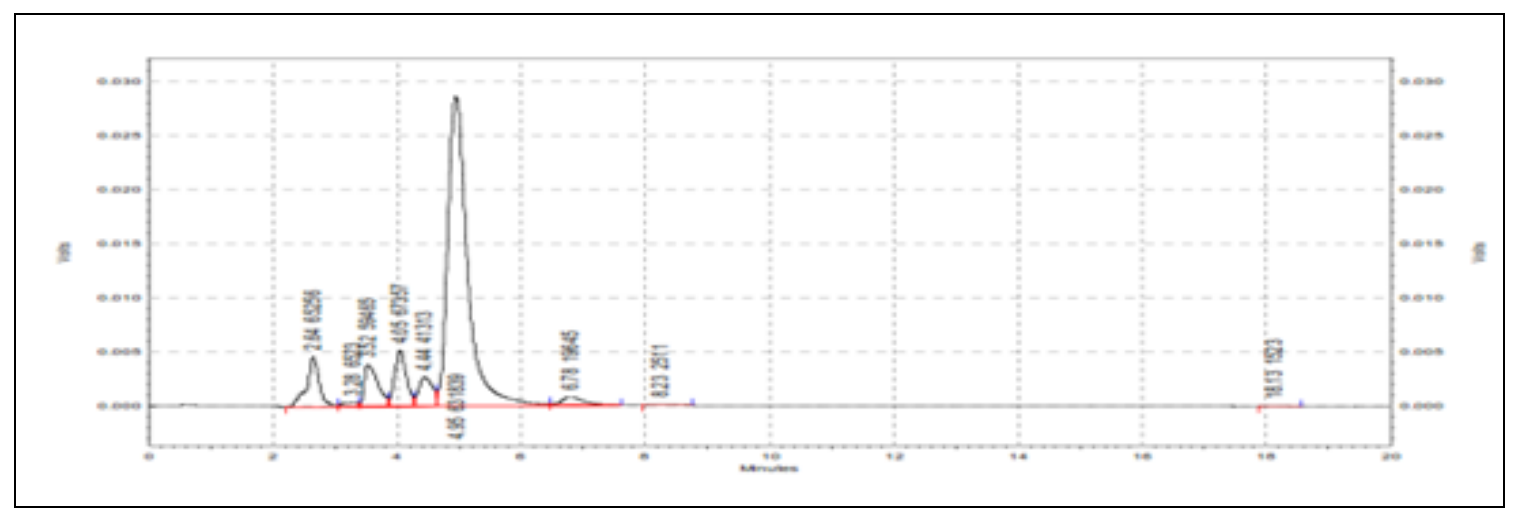

FIG. 5: BASE DEGRADATION SAMPLE WITH 0.1 M SODIUM HYDROXIDE AT ROOM TEMPERATURE WITHDRAWN AT $0 \mathrm{~h}$

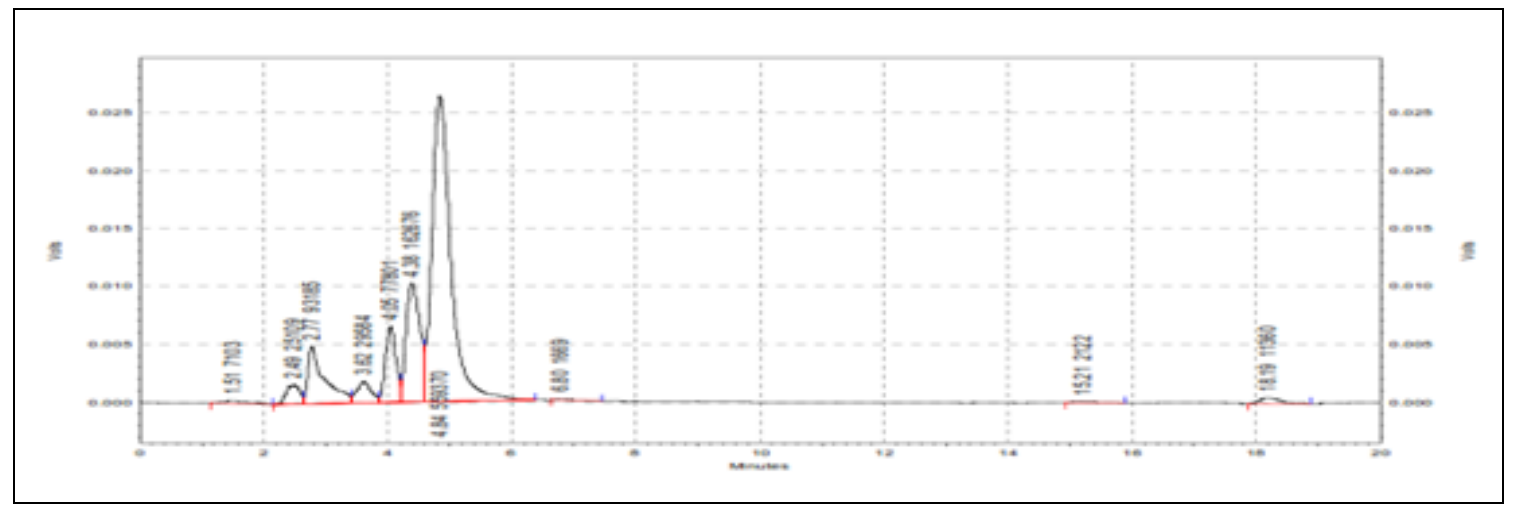

FIG. 6: BASE DEGRADATION SAMPLE WITH 0.1 M SODIUM HYDROXIDE AT ROOM TEMPERATURE WITHDRAWN AT $24 \mathrm{~h}$

Oxidative Degradation: In oxidative degradation, it was observed that the percentage degradation of pantoprazole sodium and levosulpiride at the end of $24 \mathrm{~h}$ at room temperature with $30 \%$ hydrogen peroxide was found to be 66.78 and $22.98 \%$ respectively. The percentage of degradation of drugs at various time intervals was recorded and represented in Table 5. The chromatograms were recorded and depicted in Fig. 7 to $\mathbf{1 0 .}$

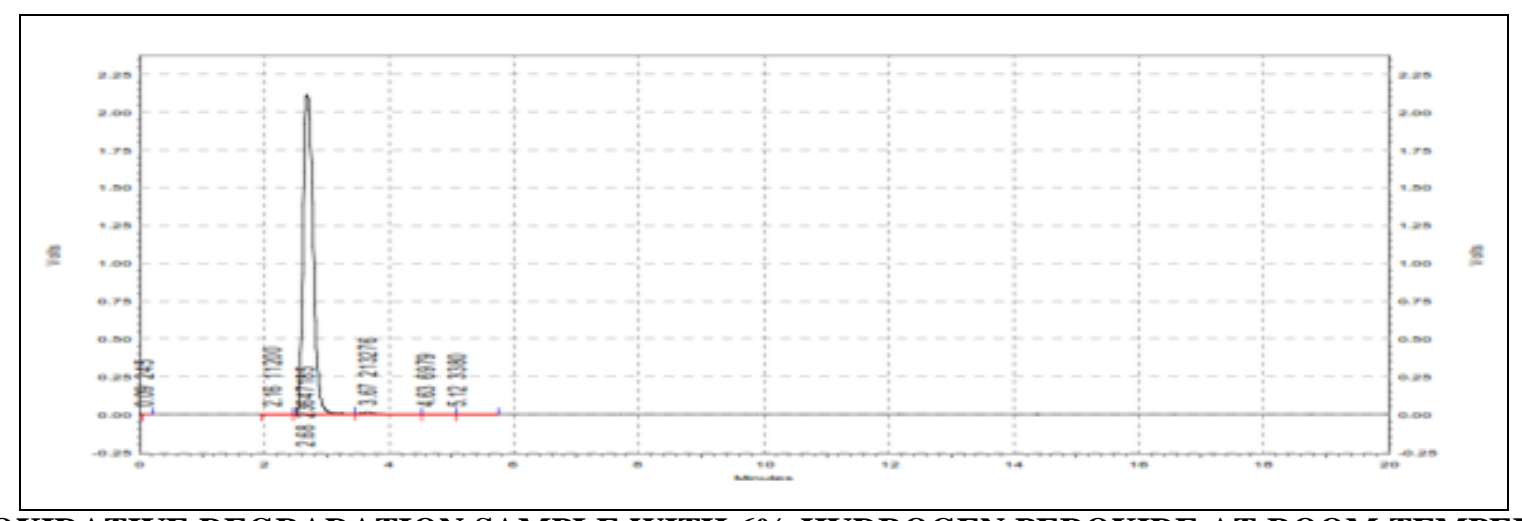

FIG. 7: OXIDATIVE DEGRADATION SAMPLE WITH 6\% HYDROGEN PEROXIDE AT ROOM TEMPERATURE WITHDRAWN AT $0 \mathrm{~h}$ 


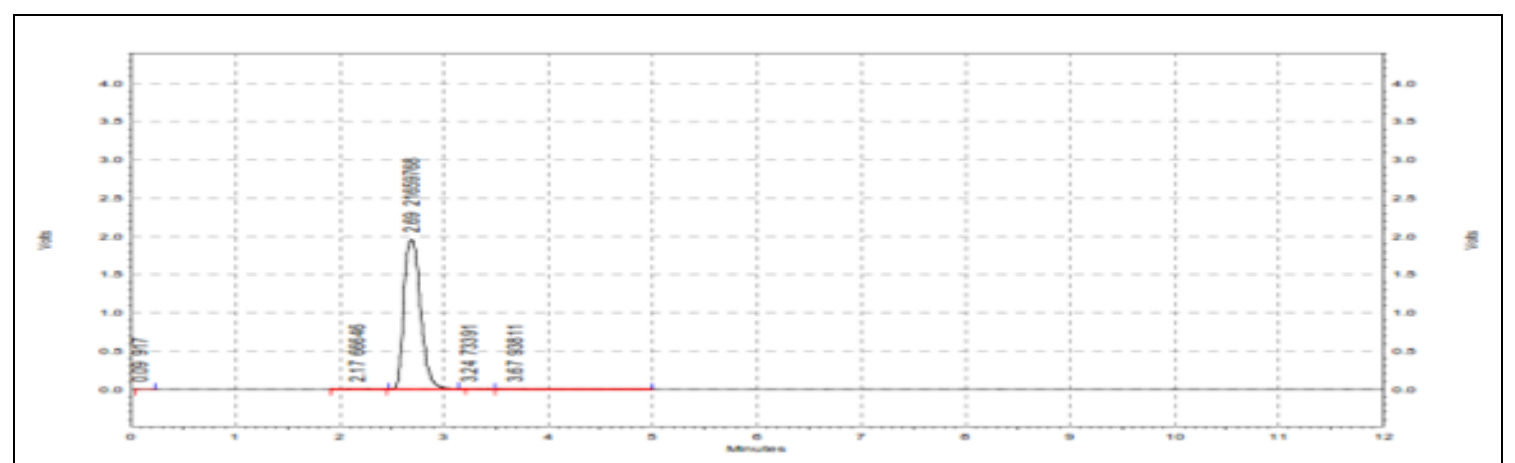

FIG. 8: OXIDATIVE DEGRADATION SAMPLE OF PANTOPRAZOLE WITH 6\% HYDROGEN PEROXIDE AT ROOM TEMPERATURE WITHDRAWN AT $24 \mathrm{~h}$

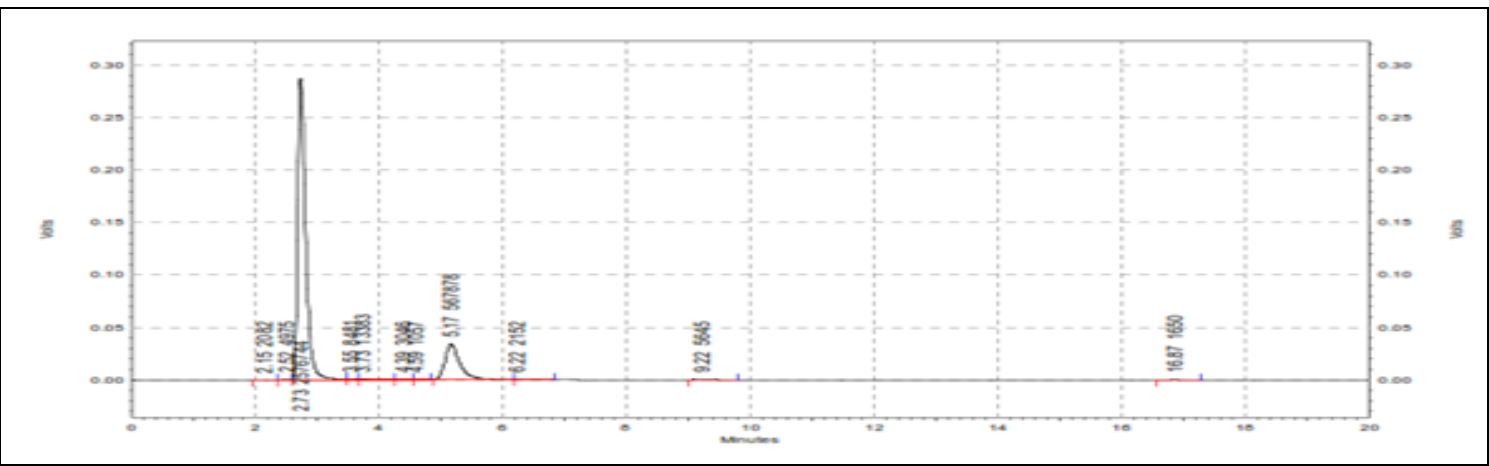

FIG. 9: OXIDATIVE DEGRADATION SAMPLE OF LEVOSULPIRIDE WITH 6\% HYDROGEN PEROXIDE AT ROOM TEMPERATURE WITHDRAWN AT $0 \mathrm{~h}$

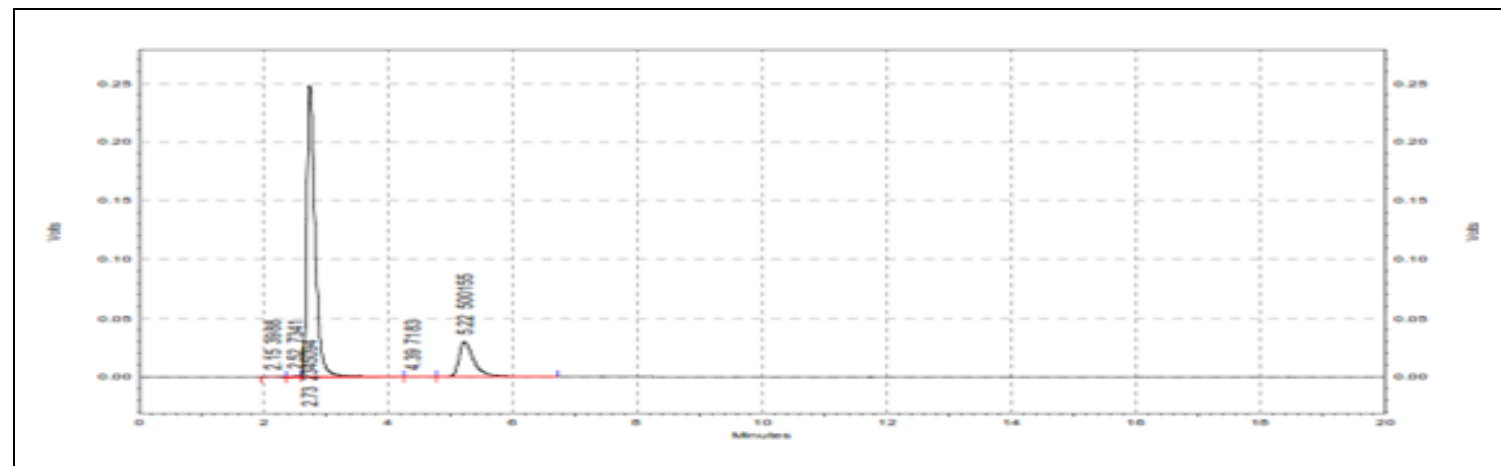

FIG. 10: OXIDATIVE DEGRADATION SAMPLE OF LEVOSULPIRIDE WITH 30\% HYDROGEN PEROXIDE AT ROOM TEMPERATURE WITHDRAWN AT $0 \mathrm{~h}$

Photodegradation: In photodegradation, the sunlight in solid form was found to be 2.756 and percentage of degradation of pantoprazole sodium $42.7 \%$ respectively. and levosulpiride at the end of $8 \mathrm{~h}$ when exposed to

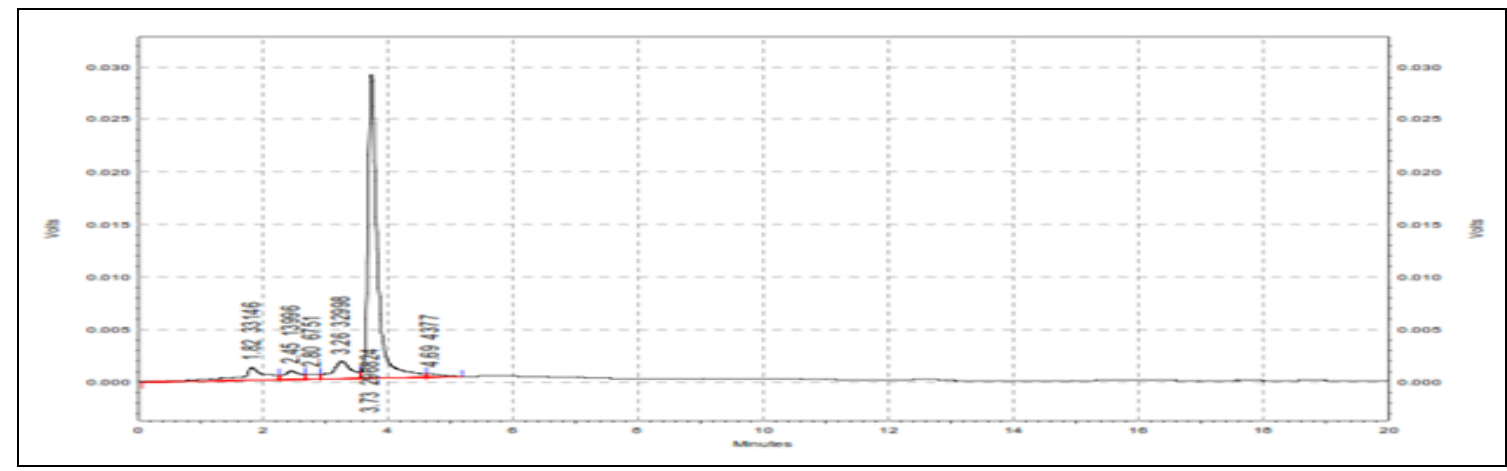

FIG. 11: PHOTOLYTIC DEGRADATION SAMPLE IN SUNLIGHT AFTER $8 \mathrm{~h}$ 
The percentage of degradation of drugs at the end of $8 \mathrm{~h}$ was recorded and represented in Table 5 . The degradation product was observed in the retention time $1.82 \&, 2.45 \mathrm{~min}$, and depicted in Fig. 11.

Thermal Degradation: In thermal degradation, the percentage degradation of pantoprazole sodium and levosulpiride at the end $8 \mathrm{~h}$ when exposed to heat at $80{ }^{\circ} \mathrm{C}$ in solid form was found to be 8.52 and $0 \%$ respectively.

The percentage of degradation of drugs at the end of $8 \mathrm{~h}$ was recorded and represented in Table 5 . The chromatograms were recorded and depicted in Fig. 12 and 13.

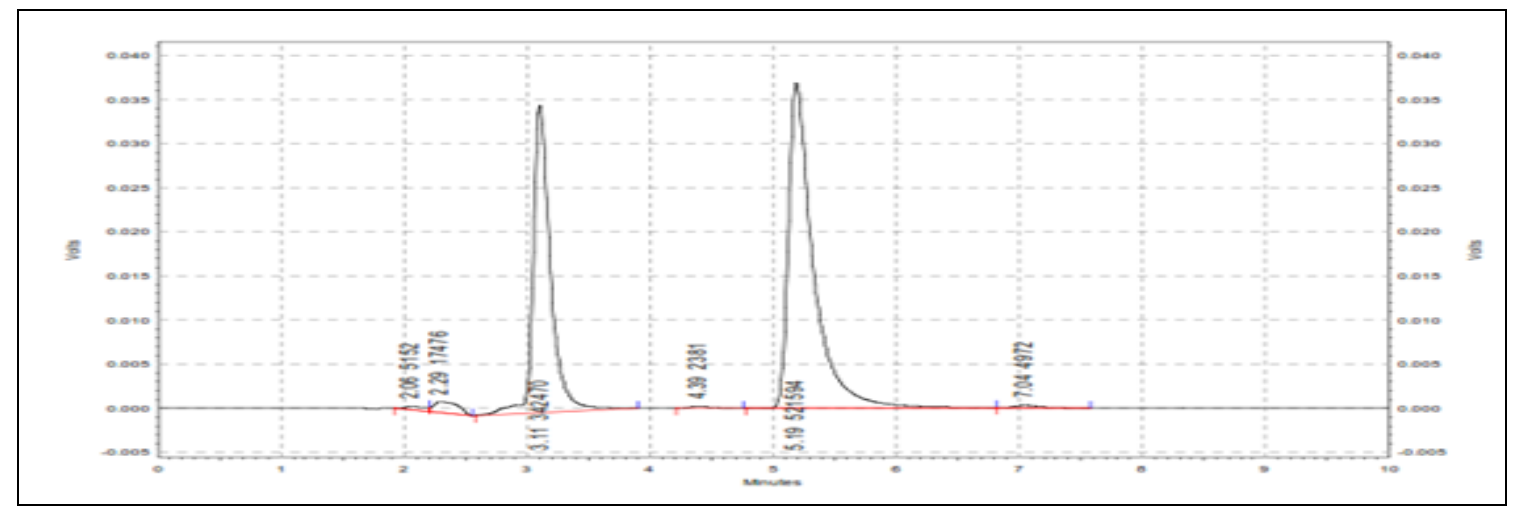

FIG. 12: THERMAL DEGRADATION SAMPLE AT $80^{\circ} \mathrm{C}$ HEAT AT $0 \mathrm{~h}$

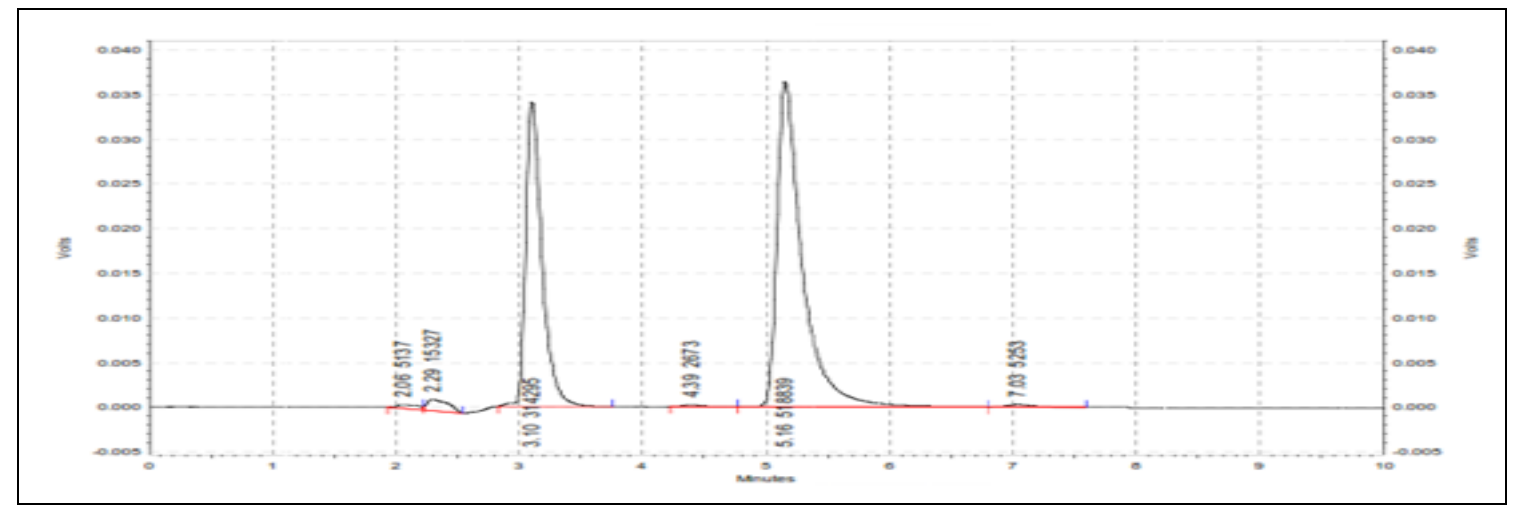

FIG. 13: THERMAL DEGRADATION SAMPLE AT $80^{\circ} \mathrm{C}$ HEAT AFTER $8 \mathrm{~h}$

CONCLUSION: A simple, specific, accurate and stability-indicating RP-HPLC method was developed for the simultaneous estimation of pantoprazole and levosulpiridein the presence of their degradation products and validated according to ICH guidelines. The method was found to be specific, accurate and robust for the routine assay. The developed method can be further applied for routine analysis in different quality control and research laboratories for analysis in a formulation.

ACKNOWLEDGEMENT: The authors are thankful to the JSS College of Pharmacy, Ooty [A Constituent College of JSS Academy of Higher Education \& Research, Mysuru] for extending their support towards the current research work.

CONFLICT OF INTEREST: The authors declare that there is no Conflict of Interest.

\section{REFERENCES:}

1. Fitton A and Wiseman L: Pantoprazole: A review of its pharmacological properties and therapeutic use in acid related disorders. Drugs 1996; 51(3): 460-82.

2. Paul W and Jungnickel: Pantoprazole: A new proton pump indibitor. Clinical Therapeutics 2000; 22(11): 1268-93.

3. Distrutti E, Fiorucci S, Hauer SK, Pensi MO, Vanaisa M and Morelli A: Effect of acute and chronic levosulpiride administration on gastric tone and perception in functional dyspepsia. Aliment. Pharmacology \& Therapeutics 2002; 16: 613-22.

4. Mucci A, Nolfe G and Maj M: Levosulpiride: A review of its clinical use in psychiatry. Pharmacological Research 1995; 31(2): 95-01.

5. Rossi F and Forgione A: Pharmaco toxicological aspects of levosulpiride. Pharmacological Research 1995; 31(2): 81-94.

6. Guslandi M: The clinical use of levosulpiride. Current Therapeutic Research 1993; 53(5): 484-01.

7. Manjunath S, Chouhan V and Sandeep S: Spectrophotometric estimation of Levosulpiride in bulk drug and formulations. International Journal of Pharmacy and Pharmaceutical Sciences 2011; 3: 135-37. 
8. Poornima R, Shetty and Patil DD: Applications of simultaneous equation method and derivative method for the determination of Rabeprazole sodium and Levosulpiride in pharmaceutical dosage form and dissolution samples. Journal of the Association of Arab Universities for Basic and Applied Sciences 2014; 15: 5360.

9. Surve S, Patwari A, Patel J, Rathod I and Chhabria M: HPTLC and HPLC method development and validation for simultaneous estimation of Rabeprazole sodium and Levosulpiride in bulk and its pharmaceutical dosage form. International Journal of Pharmacy and Pharmaceutical Sciences 2013; 5: 65-69.

10. Yoganand B, Deulgaonkar, Patel JA, Mahajan MP and Sawant SD: A simple and Validated RP-HPLC method for the simultaneous estimation of Levosulpiride and Rabeprazole sodium in bulk and Pharmaceutical dosage form. Indo American Journal of Pharmaceutical Research 2013; 3: 4017-25.

11. Sirisha A and Kumar AR: Method development and validation of simultaneous estimation of Levosulpiride and Rabeprazole in bulk and pharmaceutical dosage form by RP-HPLC. International Research Journal of Pharmaceutical and Applied Sciences 2012; 2: 49-55.

12. Agarwal N and Jagadeesh B: Development and validation of Stability Indicating RP-HPLC for the simultaneous estimation of Levosulpiride and Rabeprazole. Sodium. International Journal of Pharma and Bio Sciences 2012; 3: 718-26.

13. Mullapudi A, Pingali S and Santosh T: Development and validation of a stability-indicating method for the simultaneous determination of Levosulpiride and Rabeprazole by High-Performance Liquid Chromatography. International Journal of Pharmaceutics \& Drug Analysis 2013; 1: 25-36.

14. Pawar PD, Gabhe SY, Potawale SE and Mahadik KR: Validated normal phase HPTLC method for the simultaneous quantification of Levosulpiride and Esomeprazole in capsule dosage form. International Journal of Pharmacy and Pharmaceutical Sciences 2014; 6: 347-50.
15. Patel R, Kakadiya J, Patel P and Shah N: Development and validation of high-performance thin-layer chromatographic method for simultaneous estimation of levosulphiride and esomeprazole in combined pharmaceutical formulation. World Journal of Pharmacy and Pharmaceutical Sciences 2014; 3: 1621-36.

16. Thummala VRR, Seshadri RK, Tharlapu SSJM, Ivaturi MR and Nittala SR: Development and validation of a UPLC method by the QbD approach for the estimation of Rabeprazole and levosulphiride from capsules. Scientia Pharmaceutica 2014; 82: 307-26.

17. Patel ZN, Patel PB, Modi JD, Parikh NN, Parikh NN, Chaudhari HM, Pradhan PK and Upadhyay UM: RPHPLC method for the simultaneous estimation of Levosulpiride and Pantoprazole sodium in the tablet dosage form. Pharma Science Monitor 2014; 5: 125-32.

18. Kothapalli LC, Inamdar AA, Nanda RK and Thomas AB: Development and validation of a stability-indicating $\mathrm{rP}$ HPLC method for simultaneous estimation of pantoprazole sodium sesquihydrate and levosulphiride in a combined dosage form. International Journal of Research in Pharmacy and Science 2014; 4: 32-38.

19. Khanage SG, Shinde RC, Mohite PB, Deshmukh VK: Simultaneous estimation of levosulphiride and pantoprazole sodium in capsule dosage form by RP HPLC method. Annals of west University of Timisoara Series of Chemistry 2013; 22: 23-34.

20. Kalaiselvi $P$ and Lalitha KG: Analytical method development and validation of Levosulpiride and Pantoprazole in tablets by RP-HPLC method. Journal of Biomedical and Pharmaceutical Research 2014; 3: 75-80.

21. ICH, Q2A. Text on validation of analytical procedures, International Conference on Harmonization.International Council for Harmonisation of Technical Requirements for Pharmaceuticals for Human Use 1994.

22. ICH, Q2B. Validation of analytical procedures: methodology, International Conference on Harmonization.International Council for Harmonisation of Technical Requirements for Pharmaceuticals for Human Use 1996.

How to cite this article:

Shivaraju NH, Kowmudi G, Anoop K and Nagappan K: Stability indicating RP-HPLC method for the simultaneous estimation of pantoprazole and levosulpiride in pharmaceutical dosage form. Int J Pharm Sci \& Res 2019; 10(11): 4949-58. doi: 10.13040/IJPSR.09758232.10(11).4949-58.

All @ 2013 are reserved by the International Journal of Pharmaceutical Sciences and Research. This Journal licensed under a Creative Commons Attribution-NonCommercial-ShareAlike 3.0 Unported License

This article can be downloaded to Android OS based mobile. Scan QR Code using Code/Bar Scanner from your mobile. (Scanners are available on Google Playstore) 